\title{
Yabancı Dil Olarak Türkçe Öğrenen Öğrenicilerin Kullandığı Şikâyet Edimi Stratejileri
}

\section{Complaint Strategies Used by Learners of Turkish as a Foreign Language}

\author{
Zeynep ARSLAN* (i), Mehmet GÜRLEK** ()
}

*Milli Eğitim Bakanlığı Bakanlığı, Ankara, Türkiye

**istanbul Üniversitesi, Edebiyat Fakültesi, Dilbilimi Bölümü, Genel Dilbilimi,

İstanbul, Türkiye

ORCIDs: Z.A. 0000-0003-0126-9469;

M.G. 0000-0002-3601-8005

Sorumlu yazar/Corresponding author: Zeynep Arslan (Öğretmen),

Milli Eğitim Bakanlığı Bakanlığı, Ankara, Türkiye E-posta: ogretmenzeynep@yandex.com

Başvuru/Submitted: 05.06 .2020

Kabul/Accepted: 28.06 .2020

Atıf/Citation: Arslan, Z. \& Gürlek, M. (2020). Yabancı dil olarak türkçe öğrenen öğrenicilerin kullandığı şikâyet edimi stratejileri. Dilbilim Dergisi - Journal of Linguistics, 35, 63-88. https://doi.org/10.26650/jol.2020.010

\section{öz}

Günümüzde Türkçenin yabancı dil olarak öğrenimine ve öğretimine olan ilgi gittikçe artmaktadır. Yabancı dil olarak öğretilen diğer dillerde de olduğu gibi Türkçe öğretiminde de sadece dilsel edince odaklanan uygulamalardan iletişimsel yeterliliği edindirmeye yönelik, bütüncül bir bakış açısına geçilmesi büyük önem taşımaktadır. Bu doğrultuda yabancı dil olarak Türkçe (YADOT) öğrenicilerine söz edimlerinin öğretilmesi ve gündelik hayata uygun bir şekilde kullanımlarının sağlanması da dikkat çekilmesi gereken bir konudur. Bu nitel çalışmanın amacı YADOT öğrenicilerinin şikâyet ediminin farklı bağlamlarda kullanımında ne ölçüde başarılı olduklarını ve hangi şikâyet edim stratejilerine başvurduklarını belirlemektir. Araştırmanın yapısına uygun olan örnek olay desenine başvurulmuştur. İstanbul Üniversitesi Dil Merkezinde Türkçe öğrenmekte olan B1, B2 ve C1 seviyelerindeki 18 öğrenici ulaşılabilir örnekleme yoluyla seçilmiştir. Veriler söylem tamamlama testi uygulanarak toplanmıştır. Verilerin analizinde on bir şikâyet edim stratejisi temel alınmıştır. YADOT öğrenicilerinin bağlamlara yönelik verdiği cevapların analizinden elde edilen sonuçlara bakıldığında resmî ortamlarda şikâyet edilirken beklenenin aksine dolaylı şikâyet edim stratejilerinden çok doğrudan şikâyet edim stratejilerine başvurulduğu gözlenmiştir. YADOT öğrenicilerinin şikâyet ediminde iletişimsel yetileri verilmek istenen mesajı anlamada zorluk çekmedikleri, fakat bağlama uygun hitap biçimlerinde ve konuşmaya girişte kullanılan kelime seçimlerinde başarılı olamadıkları tespit edilmiştir.

Anahtar kelimeler: Söz edimleri, YADOT, Şikâyet edimi

\section{ABSTRACT}

The importance of learning and teaching Turkish as a foreign language is increasing every day. As is the case in the teaching of other foreign languages, the field faces a transition from practices focusing only on grammatical competence to a more holistic view in which the important end-goal is communicative competence. Teaching speech acts to learners of Turkish as a foreign language (Yabancı Dil Olarak Türkçe Öğretimi, or YADOT) and enabling them to use these speech acts in daily life is another prominent issue. The purpose of this qualitative study is to determine how successful the learners of YADOT are in their use of the complaint act in different contexts and which complaint strategies they apply. The case method was used and the participants were all at the level of B1, B2, or C1 at the Istanbul University Language Center, were selected 
through convenience sampling. The data was collected by discourse completion test, and analysis was based on 11 specified complaint strategies. This study found that learners of YADOT do not have difficulties in understanding the message being aimed at, but they are not competent enough to select the appropriate contextualized address forms or vocabulary items to initiate a dialogue.

Keywords: Speech acts, YADOT, Complaint act

\section{EXTENDED ABSTRACT}

Language learning is an essential process if individuals and societies are to interact with each other. Target languages are given foreign, second, or official status, following government policy. In the last few decades, not only teaching but also learning Turkish as a foreign language has become noticeably more important, and consequently, the number of studies on learning Turkish as a foreign language has increased. However, these studies generally focus on the question of how the learners' four skills (namely reading, writing, listening and speaking skills) can be improved, and the need for studies into various other fields of linguistics, such as speech acts, is being underestimated. For example, although the learners sampled in this study knew which vocabulary items could be used in a specific context, they did not know how to contextualize them. At this point, the issue of using speech acts appropriately within specific contexts becomes pertinent, and in this case, speech acts are mainly classified as requests, apologies, and complaints. The main purpose of this study is to draw the attention of both instructors and learners of Turkish as a foreign language to the use of complaint acts, as well as to the language structures taught in Turkish classes, and to contribute to the improvement of the quality of speech act-based language teaching materials. The study also asks whether it is the length of the time spent in Turkey, the level of Turkish-language proficiency, and/ or the number of languages spoken by the individual that negatively or positively affects an individual's choice of complaint strategies.

In terms of methodology, as per the study's design, the case method was selected as being most appropriate. Using convenience sampling, participants were selected from among the students learning Turkish at the İstanbul University Language Center, which is one of the best language centers in Turkey. In total, the group consisted of 8 females and 10 males from different countries, ranging from 18 to 25 years of age, and ranging between intermediate and advanced levels of Turkish-language proficiency. The data was collected using a discourse completion test that included ten questions based on different real-life scenarios. The participants were expected to write their answers to the questions as naturally as possible, and their answers were analyzed through 11 complaint strategies of opting out, hints, annoyance, consequences, indirect, direct, modified blame, explicit blame (behavior), explicit blame (person), request for repair, and threat.

In the analysis phase, each answer to the 10 questions was assessed, and, according to the results, it was discovered that explicit blame (person) was the complaint strategy used most often and that the participants had a tendency to use request and apology strategies instead 
of complaint ones. Moreover, we found that neither YADOT learners' Turkish-language proficiency level nor the length of time they had spent in Turkey correlated with their choice of the appropriate complaint strategies, and that the participants' grammatical competence was not as developed as their pragmatic and communicative competence. One of the most prominent findings of this study is that the participants had problems differentiating formal and informal interlocutors. The statements they used in instructor-student and neighbor-neighbor dialogues were similar to each other. Also, according to the study's results, the learners of YADOT were capable of using basic Turkish phrases but were not able to use those phrases, common Turkish greetings, and expressions in the appropriate contexts. As a result of this study based on the use of complaint strategies by learners of Turkish as a foreign language, it can be said that the pragmatic dimension needs to be taken into consideration in terms of teaching and learning Turkish as a foreign language. 


\section{Giriş}

Yabancı dil öğrenimi karmaşık bir süreçtir ve bu konunun birçok farklı açıdan incelenmesi yalnızca öğrenenlerin değil aynı zamanda öğreticilerin de bu süreci daha sağlıklı yürütebilmelerine katkı sağlayacaktır. Dilbilim çalışmaları anlambilim, sözdizimi, biçimbilim gibi alanlara yoğunlaşır. Ancak, kullanılan yapıyla ulaşması amaçlanan mesajın tutarlı olup olmamasını konu edinen edimbilim ise bu alanları birleştirici bir görev üstlenir. Mey (1993: 315) edimbilimi, "dilbilim çalışmalarının toplumsal olarak gerekli ve bilinçli olarak interaktif boyutu olarak" tanımlamış ve önemine dikkat çekmiştir. "Bununla ne demek istedi” sorusunun cevaplanması için cümledeki kelimelerin anlamının ve diziminin bilinmesi yeterli olmaz, kastedilen ifadeyi anlayabilmek için cümleyi kimin hangi bağlamda dile getirdiği sorularına cevap aranmalıdır (Birner, 2013: 1). Demirezen (1991: 281) ve Kocaman (1996: 11) tarafindan "bulunduklar1 bağlamlara bağlı olarak dil sözcelerinin anlam çalışması" ve "iletişimde dil kullanımının, özellikle tümcelerle kullanıldıkları bağlam ve durumlar arasındaki ilişkilerin incelenmesi”" olarak tanımlanan edimbilim anlambilim ile benzerlikler taşımaktadır. Bu doğrultuda Balcı (2012: 557) anlambilimi “tümcelerin sözcük anlamlarıyla" ilişkilendirirken, edimbilimi “belirli bir ifade bağlamında kastedilenlerin anlamlarıyla ilgilenmesi sebebiyle birbirlerini etkileyen farklı incelemeler bütünü olarak" ele alır

Edinç ve edim terimleri arasındaki farklılıklar ikinci dil edinimi tartışmalarında önemli bir yer tutmaktadır. Chomsky (1965: 4) bu iki önemli terim arasındaki farklılığa yeni bir bakış açısı getirerek, edinci (competence) "bir konuşucunun dili hakkındaki bilgisi” olarak tanımlarken, edimi (performance) “dilin somut durumlardaki gerçek kullanımı” olarak ifade eder ve edimin edincin doğrudan bir yansıması olduğunun altını çizer. Chomsky edinç tanımı ile "anadili konuşurunun dile ilişkin sezgizel dilbilgisi (fr. Grammaire) bilgisi”, edim olarak ifade ettiği şey ile de "dil kullanımına ilişkin bilgisidir" Polat (2010: 55). Polat bu doğrultuda edinci bilgi ve beceriyle ilişkilendirmektedir. Chomsky’nin bu ayrıma varmasında kabul edilebilir olan veya olmayan cümlelerin edim ile mi yoksa edinç ile mi ilgili olup olmamasından yola çıkmıştır. "Kabul edilebilir” terimini kâğıt kalem analizi gerektirmeden anlaşılabilen son derece doğal sözceler için kullanmaktadır. Hymes (1972) ve Campbell ve Wales (1970) edinç-edim farklılıklarına yeni bir yorum getirmişlerdir. Yazarlar "en önemli dilbilgisel yetenek olarak dilbilgisel olmayan ama bulundukları bağlama uygun ifadelerin anlaşılması ya da üretilmesini sunmuşlardır (Campbell ve Wales, 1970: 247). Değinilmesi gereken bir diğer konu ise, Grice tarafından ortaya atılan (1989) işbirliği ilkesi ve konuşma kurallarıdır. Bu ilkeye göre, konuşmaya katılan kişiler, sözcelerin yorumlanmasını daha kolay bir hale getirmek maksadıyla konuşmaya akılcı ve işbirlikçi bir şekilde katkıda bulunma çabasındadırlar. Bunu gerçekleştirirken, miktar, nitelik, ilişki ve biçim kurallarına uymaktadırlar (Grice, 1989: 26).

Söz edim kuramına bakıldığında "bireyler, bir şeyleri söylemek ve yaptırabilmek için hedef dilin sözdizimi kurallarını bilmenin ötesinde, o dile ve kültüre ait uzlaşımların da farkında olmalıdır" (Fidan, 2017: 379). Edim eylem ile ilişkilendirilirken, söz ise dil ile ilişkilendirilmiştir 
ve söz edim "oluşması için dilde gereksinim duyulan edimleri gerçekleştiren ve amacı kişilerin birbirleri karşısındaki durumlarını değiştirmek olan en küçük anlam birimi”" olarak tanımlanmıştır (Alkan, 2019: 17). Edimin gerçekleşmesi için dile ihtiyaç duyulurken, şikâyet etme, ricada bulunma, kabul etme gibi söz edimleri dil aracılığıyla gerçekleştirilir. Ellis’e (1994: 159) göre "konuşmacılar bulundukları bağlamda sözcelemi gerçekleştirirken (performance utterances) iki şey başarır ; etkileşimli edimler ve söz edimleri. Söz edimleri, dilin kullanıcıları tarafından özellikle övgü, rica ya da şikâyet gibi kişi temelli işlevlerde, spesifik davranışları sergilemek için gerçekleşen girişimleri oluşturur” Dil felsefesinin öncü isimlerinden Austin ve öğrencisi Searle anlam sorunları ve dilin kullanımına önem vermiş ve söz edimleri kuramının oluşturulmasına büyük katkılar sunmuşlardır. Austin (2009) söz edimlerini karar belirticiler (fr. Verdictifs), kullanım belirticiler (fr. Exercitifs), yükleyiciler (fr. Promissifs), davranış belirticiler (fr. Comportatifs) ve serimleyiciler (fr. Expositifs) olmak üzere beş kategoriye ayırırken Searle (2011) Austin’in önerdiği listelerin “edimsöz edimlerinden ziyade edimsöz fiilleri listesi olarak kabul edildiğini” iddia etmesine rağmen çeşitli yönlerden eleştiriler yöneltir (s:31). Searle'e (2011) göre ilk olarak listeye alınan fiillerin hepsi edimsöz fiili değildir. Örnek olarak "niyetinde olma" bir edimsöz edimi değildir. İkinci olarak da düşünür taksonominin en önemli zayıflığı olarak herhangi bir ilkeye dayandırılmaması olduğunu iddia eder. Bir diğer eleştiri ise edimsöz edimleri ve edimsöz fiilleri benzer olarak düşünülmektedir ve kategorilere ayrılırken önemli sorunların ortaya çıktığı belirtilmektedir. Ayrıca sınıflandırmalarda homojen bir yapı bulunmamaktadır. "hodri meydan demek" davranış-belirticiler kategorisinde yer alırken, erk-belirticiler arasında da bulunmaktadır. Yönlendirilen son eleştiri ise beş sınıfa ayrılan fiiller ve tanımlar arasındaki uyuşmazlık durumudur (Searle, 2006: 31-33). Ayrıca düşünür bu eleştirilerden yola çıkarak sınıflandırma yapılırken “edimsöz ereğini onun doğal sonuçlarını, uydurma doğrultusunu bir de dışavurulan içtenlik koşullarının” göz önünde bulundurulmasını önerir bu sayede "yetki sahibi kişinin rolü ve söylem bağıntıları" gibi boyutların ön plana çıkarılabileceğini iddia eder (Searle, 2006: 34). Sonuç olarak, Searle (2006, s: 169-171) edimsözleri iddia ediciler, yönlendiriciler, taahhüt ediciler, ifade ediciler ve bildirimler olarak sınıflandırır. Söz edimleri çalışmalarında rica ve özür edimleri ön plana çıksa da şikâyet edimi hedef dildeki yapıların kültür ile bağdaşık olarak kullanımı noktasında diğer edimler kadar önemsenmesi gereken bir konudur. Boxer (1991) şikâyet edimini dolaylı ve doğrudan olarak sınıflandırır; yazar (1993: 280) dolaylı şikâyeti "mevcut olmayan birisi/bir şey ya da kendisi hakkında bir muhataba yönelik tatminsizlik ifadesi" olarak tanımlanırken, doğrudan şikâyette ise muhatap ne sorumlu tutulur ne de algılanan suçu düzeltme yeteneğine sahiptir". Şikâyet ediminde kullanılan stratejilere ilişkin birçok sınıflandırma çeşidi bulunmaktadır ve toplumdan topluma değişiklik göstermektedir. Bu doğrultuda, çalışmada Trosborg (1995) tarafından oluşturulmuş Yian'ın ( 2008 ) ve Bikmen ve Martı'nın (2013) da eklemelerde bulunduğu şikâyet edim stratejileri temel olarak alınmıştır. Trosborg (1995) tarafından oluşturulan sekiz strateji (en dolaylıdan doğrudana doğru) ima, kızma, yanlış sonuçlar, dolaylı suçlama, doğrudan 
suçlama, hafif kınama, suçlama (davranış), ve suçlama (kişisel) iken ; Martı ve Bikmen (2013) bu sınıflandırmaya doğrudan davranışlar, uyarılar ve sessiz kalma olmak üzere üç yeni kategori daha eklemişlerdir.

$\mathrm{Bu}$ alanda yapılan çalışmalara bakıldığında ise, yurtiçindeki çalışmaların da İngilizce öğretimindeki edimlere odaklandığg görülmüştür. Bayat (2017) YADOT öğrenicilerinin şikâyet ve özür ediminde doğru bağlamları kullanıp kullanmadıklarını araştırmış ve şikâyet edimi için kullanılan stratejiler bakımından ana dili konuşurlarıyla yabancı öğreniciler arasında önemli farklıların, ancak özür dileme edimi stratejileri açısından da benzerliklerin bulunduğu saptanmıştır. Polat (2011) konuyu ders kitapları açısından değerlendirmiştir ve çalışmada Fransızca, Türkçe ve İngilizce ders kitapları aracılığıyla söz edimlerinin açık adına, gerçekleşme alanlarına ve biçimlerine nasıl yer verdikleri incelenmiştir. Ulaşılan sonuca göre, dil eğitimi için hazırlanmış bir kitapta söz ediniminin açık adına yer verilmesi ya da verilmemesi yanıltıcı olabilmektedir. Bikmen ve Martı (2013) tarafından yapılan araştırmada ise İngilizce öğrenen Türklerin şikâyet etme davranışları, ana dili Türkçe ve ana dili İngilizce olan bireylerle karşılaştırılmıştır Sonuçlar dilin bireysel örnekleri ana dilinden transferi yansıtır ifadesiyle çelişirken, sonuçların bir kısmı, evrensel olarak hazır edimbilimsel stratejilerin benzer strateji kullanımından sorumlu olduğunu ve kültüre özgü dil kullanımı konusunu destekler.

Araştırmanın temel amacı yabancılara Türkçe öğretimi ders kitaplarında vurgulanan dilin yanı sıra gündelik yaşamda da sık sık karşılaşılan şikâyet ediminin YADOT öğrenicileri tarafından kullanımına dikkat çekmek ve bu sayede kullanılan yazılı ve işitsel materyallerde bu edimin kullanımına yönelik etkinliklerin yeterli seviyede olmasını sağlamaktır.

Çalışmada esas alınan soru şu şekildedir;

Hem ana dili hem de yabancı dilde önemli bir yer tutan şikâyet söz edimleri, birbirinden bağımsı/gündelik hayatta karşılaşılabilecek bağlamlarda, Türkçeyi yabancı dil olarak öğrenen öğreniciler tarafından nasıl kullanılmaktadır ve bu durumlarda hangi stratejiler tercih edilmektedir?

Çalışmada cevaplanması hedeflenen temel problem ile birlikte aşağıdaki soruların da yanıtları aranmıştır:

1. Öğrenilen dilin ana dili olarak konuşulduğu bir ülkede geçirilen zamanın uzunluğu şikâyet ediminin daha etkin bir şekilde kullanılmasını olumlu veya olumsuz bir yönde etkiler mi?

2. Türkçeyi yabancı dil olarak öğrenen öğreniciler bulunduğu dil seviyesi doğrultusunda toplum dilbilgisel yeterliklere sahip midir?

3. Türkçeyi yabancı dil olarak öğrenen öğrenicilerin birden fazla yabancı dil bilmesi başvurdukları şikâyet edim stratejisi tercihinde belirleyici midir?

4. Türkçeyi B1 (orta) seviyede öğrenmekte olan öğrenicilerle ileri (C1) seviyede olanlar arasında şikâyet ediminde ortaya çıkan farklılıklar ne ölçüdedir? 
Çalışmanın temel varsayımı yabancı dil olarak Türkçe öğrenen bireylerin sınıf düzeyinde Türkçe 'ye hâkim olmalarına rağmen şikâyet edimini kullanırken istenen düzeyde kendilerini ifade edemedikleridir

\section{Yöntem}

Araştırma İstanbul Üniversitesi Dil Merkezi’nde uygulanmış olan nitel bir çalışmadır. Bu nitel araştırmanın doğasına uygun olarak örnek olay deseni tercih edilmiştir. Araştırmanın evrenini İstanbul Üniversitesi Dil Merkezi'nde Türkçe öğrenen öğreniciler oluşturmaktadır. Çalışmada örnekleme türü olarak ulaşılabilir örneklem tercih edilmiştir. Türkçeyi yabancı dil olarak öğrenen öğrenen 18 öğrenici bu çalışmanın örneklem grubunu oluşturmaktadır. İstanbul Üniversitesi Dil Merkezi’nde yabancı dil olarak Türkçe öğrenmekte olan B2, C1 ve akademik İngilizce sınıflarındaki (C2) yabancı öğreniciler arasından, sınıfların hazır bulunuşluk durumuna göre belirlenmiş ve seçilmiştir. Çalışmada kullanılan ankette kullanılan dilin doğru bir şekilde anlaşılması ve cevaplanabilmesi için ileri seviyedeki öğrenicilerin katılımına öncelik verilmiştir. Çalışmanın zamanlaması ve merkezde bulunan öğrenici mevcudundan dolayı örnekleme B2 seviyesi de dahil edilmiştir. Çalışmanın örneklemi 8 kadın 10 erkek olmak üzere 18 öğreniciden oluşturulmuştur.

Araştırmaya katılan öğrenicileri yaş dağılımına bakıldığında ise, katılımcılar üniversite öğrencisi olduğu için genel yaş aralığı 19-25 tir. Çalışmadaki örneklem topluluğunda yer alan öğreniciler uyrukları bakımından çeşitlilik göstermektedir. Öğrenicilerin uyrukları bakımından sınıflandırıldıkları tabloda da görülebileceği üzere ilk sırada 8 öğrenciyle Suriye gelmektedir; daha sonra, ikişer öğrenciyle İran, Filistin, Afganistan ve Çin gelirken, Türkmenistan ise 1 öğrenciyle bu sırayı takip etmektedir. Anketteki bir diğer önemli unsur olan dil yeterliliğine bakıldığında, katılımcıların Türkçe 'deki yeterliliği B2 (orta), C1 (ileri) ve C2 (ileri seviye/ akademik Türkçe) seviyesindedir. Ankette kullanılan dilin katılımcılar tarafından anlaşılabilmesi ve her bir bağlama yönelik cevap verebilmesi için başlangıç seviyesindeki öğreniciler çalışmaya dahil edilmemiştir (18 öğrenicinin 6’sı B2, 10’u C1 ve 2'si C2 sınıfından). Katılımcıların Türkçe öğrenmeye başlamadan önce, kaç dili etkin bir şekilde kullanabildiği de bir diğer önemli unsurdur. Bu bağlamda katılımcıların 4'ü yabancı dil olarak sadece Türkçe öğrenmektedir. 10 katılımcı Türkçeden başka yabancı bir dil daha bilirken, 2 katılımcı tanesi ise Türkçeyi üçüncü ve dördüncü yabancı dil olarak öğrenmektedir. Katılımcıların tamamı üniversite öğrencisi olduğu için Türkçe öğretimine maruz kalma süreleri büyük farklılıklar göstermemekle birlikte, katılımcıların 1'er tanesi sırasıyla 3, 5, 6, ve 7, 15 ay; 2 ve 9 senedir Türkçe öğreniyorken, 2 tanesi 8, 4 tanesi 9 ve 5 tanesi de 1 senedir Türkçe öğretimine maruz kalmışlardır.

Bu çalışmada veri toplama aracı olarak edimbilim çalışmalarında yaygın olarak kullanılan ölçme araçlarından söylem tamamlama testinden (Discourse Completion Test) faydalanılmıştır. Söylem tamamlama testinde günlük hayatta şikâyet söz ediminin kullanımını gerektirecek bağlamlar seçilmiştir. Seçilen bağlamların kapsayıcı olması sebebiyle Bikmen ve Martı (2013) 
tarafından hazırlanan söylem tamamlama testinden faydalanılmıştır. Yazarların İngilizce olarak hazırladıkları test Trosborg (1995) tarafından oluşturulmuş ve Yian (2008) tarafindan da düzenlenmiştir. Bu anket gerekli izinler alınarak bu çalışma için Türkçeye çevrilmiş ve kullanılmıştır. Anketin geçerliğini arttırmak için çalışma, iki İngilizce öğretmeni ve yabancılara Türkçe eğitiminde uzman iki kişi tarafından önce Türkçeye daha sonra tekrar İngilizceye çevrilmiş ve çeviriler karşılaştırılarak anket düzenlenmiştir. Ayrıca ankette bulunan özel isimler yaygın olarak kullanılan Türkçe isimlerle değiştirilmiştir. Aşağıda verilen örnekte de görüldüğü gibi, her katılımcıdan verilen şikâyet bağlamında, mümkün olduğu kadar doğal bir şekilde, soruları cevaplaması istenmektedir. Örneğin:

Yeni bir bilgisayar satın aldınız ve birkaç gün geçmeden ekranı kararmaya başladı. Bilgisayarınızı aldı̆̆ınız mă̆azaya gittiniz, oradaki görevliye ne dersiniz? Siz:

Türkçeyi yabancı dil olarak öğrenen öğrenicilerin şikâyet edimini araştıran bu çalışma hazırlanırken veri toplama aşamasının devamı olarak elde edilen söylemlerin analizine geçilmiştir. Yazılı verilerden yola çıkılan bu çalışmada elde edilen bulgular kategorize edilmiştir ve yazım sürecine başlanmıştır. Araştırmadan elde edilen veriler, katılımcıların söylem tamamlama testindeki her bir bağlama verdikleri yanıtların içerikleri çözümlenerek elde edilmiştir. Trosborg'un (1994) belirlemiş olduğu sekiz strateji Bikmen \& Martı (2013) tarafından geliştirilerek on bir stratejiye dönüştürülmüştür. Bu kaynakların seçilme sebebi kapsamlı olmaları ve her kültürden topluluğa hitap edebilecek şekilde kültürel öğeler içermemesidir.

Katılımcılar tarafından verilen yanıtların içerikleri çözümlenirken, yanıtlardaki edimsel stratejinin, çalışmanın başında belirlenmiş olan on bir adet şikâyet edim stratejilerinden hangisine veya hangilerine daha yakın olduğu saptanmıştır. Tek puanlayıcı yanlılığını önlemek amacıyla, bu saptama yabancı dil olarak Türkçe öğretiminde uzman olan iki değerlendirmeci tarafından yapılmış ve elde edilen sonuçlar karşılaştırmalı olarak değerlendirilmiştir. Testteki sorulara verilebilecek cevapların çeşitliliğinden dolayı oluşabilecek belirsizlikler tartışma ve uzlaşma yoluyla ortadan kaldırılmıştır.

\section{Bulgular}

\subsection{YADOT Öğrenicilerinin Şikâyet Edimini Farklı Bağlamlarda Kullanımları}

Çalışmanın temel varsayımı yabancı dil olarak Türkçe öğrenen bireylerin sınıf düzeyinde Türkçe 'ye hâkim olmalarına rağmen şikâyet edimini kullanırken istenen düzeyde kendilerini ifade edemedikleridir. Bu çalışmada orta ve ileri düzeyde Türkçe bilgisine sahip yabancı öğrenicilere, şikâyet edim kullanım becerilerini görmek maksadıyla, günlük hayatta karşılaşabilecekleri 10 farklı duruma yanıt vermeleri istenmiştir. Bağlam testindeki amaç, belirtilmiş olan varsayımın doğru olup olmadığının görülmesi ve çalışmanın bir diğer önemli parçası olan alt sorulara 
yanıt bulunmasıdır. Söylem tamamlama testindeki her bir bağlama yönelik verilmiş yanıtlar ayrı ayrı değerlendirilecek, çoğunlukla hangi şikâyet edim stratejilerinin tercih edildiği ve bu stratejilerin bulunduğu bağlama uygun olup olmadığı da değerlendirilecektir.

Şikâyet edim bağlamlarında hangi stratejinin veya stratejilerin kullanıldığı belirlenirken, Trosborg'un (1994) oluşturmuş olduğu ve Bikmen \& Martı (2013) tarafından geliştirilen on bir strateji temel alınmıştır. Temel şikâyet ulamlarında kullanılan stratejiler "açık bir sitem belirtmeme, hoşnutsuzluk, suçlama, kınama, doğrudan davranış” olarak gruplandırılırken; "ima, kızma, yanlış sonuçlar, dolayl suçlama, doğrudan suçlama, hafif kınama, suçlama (davranış), suçlama (kişisel) doğrudan davranışlar, uyarılar ve sessiz kalma” olarak da detaylandırılmıştır. Ayrıca bu stratejiler dışında farklı yönelimlere de rastlanılmıştır. Bununla birlikte her bir bağlamda verilen durumların, konuşmacı-dinleyici rollerinin ve bulunmaları istenen ortamları daha net bir şekilde göstermek maksadıyla Tablo 3.1 hazırlanmıştır.

Tablo 3.1: Söylem Tamamlama Testindeki Durumların Kategorize Edilmesi

\begin{tabular}{|c|c|c|c|}
\hline $\begin{array}{l}\text { Bağlamda Verilen } \\
\text { Durum }\end{array}$ & Şikâyetçinin Rolü & Muhatabın Rolü & Ortam \\
\hline 1. Kırık Telefon & Müşteri & Müşteri Hizmetleri & Alışveriş \\
\hline 2. Sinemada Gürültü & Belirtilmemiş & Belirtilmemiş & Sinema/Kamusal Alan \\
\hline 3. Kardeşin Sorumsuzluğu & Kardeş & Kız Kardeş & Havalimanı \\
\hline 4. TV Programı Seçimi & Belirtilmemiş & Ev Sahibi & Sosyal Çevre \\
\hline 5. Kızgın Baba & Evlat & Baba & Aile Ortamı \\
\hline 6. Aracın Su Sıçratması & Yolcu/Yaya & Sürücü & Kamusal Alan \\
\hline $\begin{array}{l}\text { 7. Çöpün Dışarı } \\
\text { Çıkarılması }\end{array}$ & Komşu & Komşu & Sosyal Çevre \\
\hline 8. Sinava Kabul Edilme & Öğrenci & Sinav Gözetmeni & Eğitsel Alan \\
\hline $\begin{array}{l}\text { 9. Öğretmenin } \\
\text { Unutkanlığı }\end{array}$ & Öğrenci & Profesör & Eğitsel Alan \\
\hline 10. Gürültülü Komşu & Komşu & Komşu & Sosyal Çevre \\
\hline
\end{tabular}

(Uyarlanmıştır, Bikmen \& Martı (2013: 256))

\subsubsection{Bağlamda kullanılan şikâyet edim stratejilerinin değerlendirilmesi}

Yeni bir telefon satın aldın ama eve geldiğin zaman telefonun düzgün çalışmadığını fark ettin. Mă̆azaya tekrar gittin ama satıcı sana yardım etmiyor. Ayrıca paranı da geri vermeyecekler. Bu durum seni üzüyor. Şirketi arlyorsun ve müşteri temsilcisine (Ali) problemini anlatıyorsun. Ona ne dersin?

Söylem tamamlama testindeki ilk bağlamda verilen durum günlük hayatta herhangi bir eylem esnasında karşılaşılabilecek bir rahatsızlığa verilecek yanıtlarla ilgilidir. Birinci bağlama yönelik verilen tüm yanıtlar incelendiğinde, öncelikle her bir katılımcının bağlamda verilen 
durumu farklı kelime ve cümle yapılarıyla tekrar ifade ettiği ve bu bağlamda kullanılan yaygın stratejinin doğrudan suçlama olduğu görülmüştür. Soruda geçen müşteri temsilcisi, şirket ve satıcı firma öğeleri doğrudan suçlanmıştır. Katılımcıların hiçbiri sessiz kalma stratejisini tercih etmemiştir. Doğrudan suçlamadan sonra en çok tercih edilen strateji ise tehdittir. Katılımcılardan biri "Konuyu arkadaşlarıma da anlatacağım” (Katılımc1, 2) cevabıyla muhatabını tehdit ederken, tehdit stratejisine yönelen diğer katılımcılar ise "Polise gidip şikâyet edeceğim”" (Katılımc1, 8) ve "şikâyet edeceğim”" (Katılımc1, 9) şeklinde yanıtlar vermişlerdir. Katılımcılardan yalnızca biri bağlamda geçen müşteri temsilcisi Ali’yi etkin özne yerine koyup Ali karakterini yönlendirmeyi tercih etmiştir; "Ali mă̆azanın müdürü ile gidebilir” (Katılımc1, 16). Bu durumda şikâyet ediminden çok tavsiyeye yönelik bir yanıt tercih edilmiştir. Bununla birlikte, "Senden yardım istiyorum” (Katılımc1, 12) ve "Sizden rica etsem" (Katılımc1, 13) yanıtlarında görüldügü gibi, çalışmada esas alınan on bir şikâyet edim stratejilerinden farklı olarak rica edimini de kullanan katılımcıların olduğu saptanmıştır.

\subsubsection{Bağlamda kullanılan şikâyet edim stratejilerinin değerlendirilmesi}

Sinemadasın, büyük bir ilgiyle filmi izliyorsun. Ama arkanda oturan insanlar misır yerken çok gürültü yapıyorlar. Gürültü giderek artıyor ve sen artık filme odaklanamıyorsun. Onlara ne dersin?

Söylem tamamlama testinin ikinci bağlamında sunulan olayda ise sinema gibi sosyal hayatta sık sık gidilen bir yerde yaşanabilecek bir durum verilmiştir. Bu bağlamda verilen durumda bir katılımcı (Katılımcı, 8) açık bir sitem belirtmemiş ve sessiz kalmıştır. Aynı bağlamda en çok ön plana çıkan çıkarım ise katılımcıların rahatsızlıklarını farklı kalıp kelimeler kullanarak ifade etmeleridir. "Pardon, bakar mısınız, film izlemek istiyorum ama çok gürültü yapıyorsunuz, lütfen” (Katılımc1, 10). Söz edimlerinin günlük hayatta kullanımına bakıldığında birden fazla söz ediminin tek bir bağlamda kullanılabileceği görülebilir. Bu bağlamda da katılımcılar muhatabına yönelik şikâyette bulunurken daha çok rica edimine yönelmişlerdir. “Lütfen sesinizi kısabilir misiniz?” (Katılımcı, 5) yanıtında olduğu gibi katılımcılar tarafından genellikle "lütfen, pardon, rica etsem" gibi ifadelerin kullanıldığı saptanmıştır. Bununla birlikte kalıplaşmış bir ifade olan "lütfen sessiz olabilir misiniz" cümlesine sıkça rastlanmıştır. Bunun altında yatan sebeplerden biri kalıp ifadelerin yabancı dil öğrenicileri tarafından kolaylıkla ezberlenip kullanılabiliyor olmasıdır ancak verilen bağlamda kibar bir rica ile başlayan cümleler, bağlama uygun olmayan kelime seçimlerinden dolayı kaba bir yanıta dönüşmüştür. "Pardon, ben odaklanmaya çalışıyorum ama sizin yüzünüzden olmuyor. Mısır yerken biraz ses çıkarmayı keser misiniz? Lütfen” (Katılımc1, 14), “Lütfen biraz adap lazım” (Kat1lımc1, 15) ve "Lütfen biraz sakin olabilir misiniz?” (Katılımcı, 18) yanıtlarında kullanılan ifadeler oldukça kibar olarak yorumlanabilirken, kullanılan diğer kelimeler ifadenin kibarlıktan uzak bir şekle dönüşmesine sebebiyet vermiştir. Bu bağlam doğrultusunda, katılımcılar tarafından tercih 
edilen bir diğer şikâyet edim stratejisi de birinci bağlamda olduğu gibi doğrudan suçlamadır. $\mathrm{Bu}$ bağlamda rahatsızlığa sebebiyet veren unsur doğrudan kişiler olduğu için suçlamalar da açıkça ifade edilmiştir; "Sesiniz çok yüksek oluyor ve sizin yüzünden filme odaklanamıyorum. Sesinizi kısabilir misiniz?” (Katılımc1, 12).

\subsubsection{Bağlamda kullanılan şikâyet edim stratejilerinin değerlendirilmesi}

Kız kardeşin havaalanında Kanada'ya olan uçuşunu bekliyor. O, uzaklara gideceği için biraz endişelisin. Kanada'ya varır varmaz seni araması için ona söz verdiriyorsun ama o unutuyor. Bir hafta sonra seni arıyor. Kız kardeşine verdiği sözü hatırlatıyorsun ama o inkâr ediyor. Ona ne dersin?

Testin üçüncü bağlamında verilen durum her ne kadar havalimanında geçiyor gibi bir algı oluştursa da hazırlanmasındaki amaç, günlük hayatta sıkça karşılaşılan ve rahatsızlığa sebebiyet verebilen söz tutmama ve muhatabın uyarılara rağmen sorumluluklarını yerine getirmeme durumlarını katılımcıların zihninde canlandırmaktır. Yanıtların tümü incelendiğinde testte bulunan diğer soruların aksine, bu soru daha kısa ifadeler kullanılarak yanıtlanmıştır. Bu yüzden kullanılan stratejilerin çeşitliliği daha azdır. Bunun altında yatan sebep durumun katılımcılar tarafından içselleştirilmemesi olarak gösterilebilir. Dikkat çeken bir diğer husus ise ciddiyet gerektiren bir konunun "ahh, aşk olsun, tüh” gibi bağlamdan uzak ünlemlerle ifade edilmesidir. Ayrıca katılımcılardan biri açık bir sitem belirtmemiştir. Günlük hayatta daha şiddetli tepkiler verilebilirken, katılımcılardan bazıları sitem belirtmemiş ve sadece hafif kınama ile yanıt vermişlerdir. Katılımcıların “İşsaallah gelecek zamanda görüşürüz.” (Katılımc1, 17), "Tamam sıkıntı yok” (Katılımc1, 11), "Ben de unutacaksın Tüh” (Katılımc1, 5) ve "Hiç sorun değil” (Katılımcı, 14) yanıtlarından yola çıkılarak bu durum örneklendirilebilir. Bu bağlamda verilen durumda ön plana çıkan strateji ise tehdit, hoşnutsuzluk ve suçlamadır. "Tamam sen hatırlamıyorsun ama benim zamanim da gelecek, o zaman hatırlarsin” (Katılımc1, 13), “Annene söyleyeceğim” (Katılımc1, 9) ve "Hiç sorun değil, sen unutmuşsun ama ben şimdiye kadar hatırlıyorum. Birgün ben de aynı şey yapacağım o zaman anlayacaksın” (Katılımc1, 14) ifadelerinde şikâyetin yöneltildiği muhatap olası bir durumla tehdit edilmiştir. Yanıtlarda kullanılan kızgınlık ve doğrudan suçlama stratejilerine bakıldığında "Nasıl unutursun, sen bana söz verdin” (Katılımc1, 10) ve "Uçă̆ binmeden önce bana söz verdin” (Katılımc1, 7) söylemlerinde katılımcılar rahatsız oldukları durumdan dolayı muhatabını sorumlu tutmuşlardır. Bununla birlikte diğer iki bağlama benzer olarak şikâyete sebebiyet veren etmenler açılklanmıştır; “"'Merak olduğumdan söylüyorum ve onu bu işi yapmamaya ikna ediyorum” (Katılımc1, 4), "Madem inkar ediyor, hiçbirse ona söylemeyeceğim, yalnı gideceğiz tabi ki üzülüyorum ama farketmez ona küstüyeceğim” (Katılımc1, 2) ve "Ona çok merak ettiğimi ve ona kızdı̆̆ımı söyledim” (Katılımc1, 3). 


\subsubsection{Bağlamda kullanılan şikâyet edim stratejilerinin değerlendirilmesi}

Sen ve bir grup arkadaşın Ali'nin evine uğruyorsunuz, atıştırmalık yiyor ve bir ünlü hakkındaki TV programını izliyorsunuz. Sen bu ünlüden nefret ediyorsun; ama hiçbir şey demiyorsun ve 15 dakika boyunca izliyorsun. Sonunda dayanamıyorsun. Bir şey söyleme ihtiyacı duyuyorsun. Onlara ne dersin?

Söylem tamamlama testinde verilen dördüncü bağlama bakıldığında, şikâyetçi ve şikâyetin yöneltildiği kişiler sosyal bir ortamda bulunmaktadır. Burada örneklendirilen durum, istenmeyen bir televizyon programı izlenirken oluşan rahatsızlıktan ziyade, bireyin tahammül edemediği bir senaryo karşısında vereceği tepki doğrultusunda kendini ifade edebilme becerisidir. İlk olarak iki katılımcı sitemlerini belirtmemiştir. Bu bağlamda ön plana çıkan sonuç katılımcıların şikâyetlerinin sebebini detaylandırarak anlatmalarıdır. Belirtilen bağlam doğrultusunda yanıtlar analiz edildiğinde, katılımcıların şikâyet nedenlerini belirsizlikten uzak bir şekilde açıklayabildiği görülmüştür; "Arkadaşlar ben bu ünlüden nefret ediyorum başka bir program izleyelim" (Katılımc1, 5), "Sizin için 15 dakika ünlü programın izliyorum ama bu programı hiç sevmiyorum Onu değiştirebilir misiniz?" (Katılımc1,12), "Ben beraber eğlendiğimiz için geldim ama siz sadece kendinizi düşünüyorsunuz. Lütfen şimdi hepimizin sevdiğimiz bir film izleyelim bu programı başka bir zaman izleyelim" (Katılımc1, 13) ve "Yeter artık ben çok sılkıldım çünkü asla ünlüyü sevmem değiştirebilir misiniz lütfen" (Katılımc1, 14). Dikkat çeken bir diğer strateji ise çalışmada esas alınan on bir stratejiden farklı olarak katılımcıların muhataplarına farklı önerilerde bulunmalarıdır ve bir bakıma bu durum sezdirim stratejisi kapsamında değerlendirilebilir; "Sıkıldığımı söylüyorum ve lütfen başka bir şey yapabilirim yapmabildiğimiz söyeceğim başka bir film izlemek gibi” (Katılımc1, 4), “...başka bir program izleyelim” (Katılımc1, 5), “...lütfen şimdi hepimizin sevdiğimiz bir film izleyelim” (Katılımc1, 13) ve “...başsa bir kanal değisştirebilir miyim?” (Katılımc1, 16). Bununla birlikte bir önceki bağlamda da olduğu gibi "lütfen" ifadesi söylemi daha kibar bir hale getirmek için kullanılmıştır ve "yeter artık, oooh" (Katılımc1, 14 ve 18) ünlemleri rahatsızlığın derecesine arttırmıştır ve "Yeter artık ben çok slkıldım çünkü asla ünlüyü sevmem değiştirebilir misiniz lütfen" (Katılımcı, 14) cevabında "yeter artık ve lütfen" ifadeleri bir zıtlık oluşturmaktadır. Bu bağlamda verilen durumda tercih edilen bir diğer strateji ise tehdittir; "Hiçbir şey demiyorum eve geri dönemiyorum işte bu" (Katılımc1, 1). Son olarak soruda bulunan olayda muhataplar doğrudan suçlu iken katılımcılardan sadece biri muhataplarını doğrudan suçlamıştı;; “... ama siz sadece kendinizi düşünüyorsunuz..." (Katılımc1, 13).

\subsubsection{Bağlamda kullanılan şikâyet edim stratejilerinin değerlendirilmesi}

Baban bir iş bulman ve biraz para kazanman konusunda ısrar ediyor. Bugünlerde iş bulmanın ne kadar zor olduğunu anlamıyor. Kahvaltıda onunla konuşuyorsun. Hâlâ bir iş bulamadığın için sana çok klzgın. Ona ne dersin? 
Bu bağlamda verilen durumda şikâyet eden kişi bir evlat iken, rahatsız olunan ve şikâyetin yöneltildiği kişi ise bir babadır. Şikâyetçi ve muhatabın aile ortamında şikâyet edimini kullanacakları bir ortamın oluşturulması düşünülmüştür. Bireylerin yaşantısına bakıldığında en çok zaman harcanan bağlamlardan birisi de aile yaşantısıdır. Bu yüzden Türkçe öğrenen bir yabancının bu tür bir iletişimi anlamada ve fikir yürütmede beceri geliştirmesi önemlidir. Bu ihtiyaca yönelik hazırlanmış olan beşinci bağlamda verilen durumdaki yanıtlar analiz edildiğinde, çalışmada esas alınan stratejilerin dışında, verilen bağlamın da etkisinden dolayı, katılımcılar muhatabını ikna etmeye çalışmışlar ve durumu düzelteceklerine dair vaatlerde bulunmuşlardır; "Biraz iş bulmak zorluğunu söylerim. Zamana ihtiyacın varolığını söylerim ve kesin işi bulucağımı söylerim” (Katılımc1, 3), "Bizim çağamızda hayat çok zor ona anlamaya çalışıyorum ve eskiden iş bulmaya uğraşıyorum" (Katılımc1, 4), "Haberi görmedin mi babam hayatı çok zor issiz isteyen kişi yok beni inanarak bekler misin?” ( Katılımc1, 6), "Baba Vallahi arlyorum, ama bulamıyorum. O kadar kolay bildiğin gibi de ğil”" (Katılımc1, 7), "Beni inansın Babam. Ben Ay sonunda iş bulacakımtır. Para kazanacağımdır.” (Katılımc1, 9), “İ̧̧ bulmak için çok denedim” (Katılımc1, 12), “Biraz sabırlı olmamı lazım...", (Katılımc1, 13) ve "Babam ben seni çok seviyorum ve ben biliyorum sen her zaman ben başarll ve çalışkan istiyorsun ben her gün iş arlyorum. Biraz zor ama Aramak durmadım." (Katılımcı, 18). Özellikle iki katılımcı tarafından kullanılmış olan "babam" ana dili Türkçe konuşuru için ebeveynle birebir gerçekleşen diyaloglarda sıkça tercih edilen bir hitap ifadesi değildir; bu kullanımın iki katılımcının ana dilinden ve cinsiyetinden kaynaklandığ düşünülebilir fakat katılımcılardan biri Suriyeli bir erkek diğeri ise Koreli bir kadındır. Çalışmada esas alınan stratejiler kapsamında bakıldığında ise, ön plana çıkan strateji doğrudan ve dolaylı suçlamadır. Şikâyet edilen durum oldukça somut olmasına rağmen, katılımcılar genel olarak rahatsızlıktan "hayat"1 ve dolayısıyla hayat şartlarını sorumlu tutmuşlardır; "Zamanlarımız sizinki benzemez! Ben üç dil biliyorum ve yüksek lisansına sahibim artık iş bulamam düşünsene bunu hatım mı?” ( Katılımc1, 1), "Bizim çağamızda hayat çok zor...” (Katılımc1, 4), "Haberi görmedin mi babam hayatı çok zor işsiz isteyen kişi çok...” (Katılımc1, 6), “...ama iyi iş bulmak çok zor...” (Katılımcı, 13). Genel olarak somut bir kurum veya kişi suçlanmasa da dolaylı bir suçlama olduğu da söylenemez. Sadece katılımcılardan birinin yanıtı dolaylı suçlama ve hafif kınama stratejisi kapsamında değerlendirilebilir; "Bence Sen bir Yarı zamanli iş bulabilirsin" (Katılımc1, 7). Yanıtlar doğrultusunda ele alınabilecek bir diğer strateji de ricadır; "Beni inanarak bekler misin?" (Katılımc1, 6), "Sabirlı olman lazım” ve "Sabır olun” (Kat1lımc1, 15-16). Son olarak da dört katılımcı açıkça bir sitem belirtmemiştir; "Tamam deyim, sadece beklemek zorunda kaldım çünkü yapacak bir şey yok” (Katılımcı, 2).

\subsubsection{Bağlamda kullanılan şikâyet edim stratejilerinin değerlendirilmesi}

Cadde boyunca yürüyorsun. Çok yağmur yağlyor. Bir araba yanından geçiyor ve pantolonuna kirli su sıçratıyor. Sürücü kırmızı ışıkta duruyor. Muhtemelen 17-18 yaşlarında genç bir erkek. Ona ne dersin? 
Bu bağlamda ele alınan durumda şikâyetçi bir yolcu ve şikâyetin yöneltildiği muhatap ise bir sürücü iken, olay sokak veya cadde gibi kamusal bir alanda gerçekleşmektedir. Yaşanılan iklime göre değişiklikler söz konusu olsa da olay gündelik hayatta sıkça karşılaşılabilecek bir durumdur. Özellikle hiç tanınmayan bir kişi tarafından sebebiyet verilen hem fiziksel hem de manevi bir rahatsızlık söz konusu olduğu için yanıtlarda verilen tepkiler de oldukça farklılaşmıştır. Analiz edilen ilk beş bağlamdan farklı olarak katılımcılar beddua ve küfür gibi daha ciddi sayllabilecek tepkiler vermişlerdir; "küfür ederim”, "onu vuracağım”, "küfür ederim sessizce”, “Allah sana affediyor" (Katılımc1, 3, 5, 6, 7, 16). Verilen bu yanitlar katılımcıların anket yönergelerinde belirtilen mümkün olduğunca doğal olma talebini destekler doğrultudadır. Ayrıca "Pardon, bakar mısın, çok hızlı araba kullanıyorsun ...” (Katılımc1, 10), "Ne yapıyorsun? Nasıl sürüleceğini bilmiyor musun?...Bak pantolonuma ne yaptın. Lütfen dikkat et" (Katılımc1, 14) cevapları da bu varsayımla örtüşmektedir. Çünkü gündelik hayata bakıldığında ani gelişen ve sert tepkiler verilebilecek bir durum olduğu için, açık bir sitemden kaçınılan "Şimdi sinirli olacă̆ım ama bir şey demeyeceğim” (Katılımc1, 4), yanıtı ve “...lütfen dikkat et efendim” (Katılımc1, 14) yanıtı gerçeklikten uzak olarak değerlendirilebilir. Ayrıca dikkat çeken bir husus ise katılımcılardan birinin kullanmış olduğu "efendim" ifadesidir; "Ne yapıyorsun? Nasıl sürüleceğini bilmiyor musun?...lütfen dikkat et efendim” yanıtı gerçeğe uygun bir kullanımla başlamışken, daha çok emir komuta zincirlerinde tercih edilen "efendim" sözcüğü ile bitirilmiştir. Bu bağlamdaki cevapların analizinde öne çıkan şikâyet edim stratejileri ise doğrudan suçlama ve hafif kınama iken, "baksana bana su sıçradın dikkat etsin" (Katılımcı, 9) cevabında da olduğu gibi uyarıda bulunulan ifadelere de başvurulmuştur.

\subsubsection{Bağlamda kullanılan şikâyet edim stratejilerinin değerlendirilmesi}

Komşunun oğlu Ali çöpünü senin ön kapının yanına koymuş. Çöp kötü kokuyor ve muhtemelen senin sağlığın için zararlı. Bu durumdan hiç memnun değilsin ve onunla konuşmaya karar veriyorsun. Kapıyı çalıyorsun ve Ali açıyor. Ona ne dersin?

Söylem tamamlama testindeki bu bağlamda yanıtlanması istenen sorudaki olay komşuluk ilişkilerini kapsamakta iken, şikâyette bulunan ve şikâyete maruz kalan taraflar komşudur. Bireylerin yaşamlarını sürdürdüğü yerler farklılık gösterebilirken, ikamet edilen binalar yaş ve gelir seviyesine göre yurt, apartman veya huzurevi olabilir. Yalnız tüm yaşantıların ortak noktası ortak kullanım alanlarından ve bireylerin birbirine karşı olan sorumluluklardan oluşabilecek problemlerdir. Bu doğrultuda hazırlanmış olan bağlamda katılımcıların cevapları çeşitlilik göstermektedir. Öncelikle üç katılımcı açıkça bir sitem belirtmemiştir; "kapıya çöp koydum ve giderim” (Katılımc1, 11) cevabı sözlü bir yanıttan ziyade fiziksel bir tepkiyi destekler niteliktedir. Yanıtlarda en çok dikkat çeken nokta "ă̆abi” (Katılımc1, 1) ifadesidir. Gündelik hayatta samimi ilişkiler geliştirilen kişilerle iletişimde kullanılan bu ifade, katılımcının Ali’yi tanıyor olduğu düşünülürse, kullanıldığı bağlama uygun düşebilir. Aksi takdirde sosyal 
mesafenin bulunduğu bir bağlamla örtüşmeyebilir. Ayrıca katılımcıların çoğu rahatsızlığını doğrudan belirtmek yerine herhangi bir şikâyet edimine başvurmadan önce selam vermeyi ve bu sayede konuya giriş yapmayı tercih etmişlerdir; “Tamam selam söyleyim...” (Katılımc1, 1) ve "Pardon nasılsınız? (Katılımcı, 10) cevapları ile örneklendirilebilir. Katılımcıların verdiği yanıtlardan biri olan "Merhaba Ali, nasılsın, iyi misin?...” (Katılımc1, 18) ifadesi ise doğallıktan ziyade kalıp bir ifadeye daha yakın gözükmektedir. "Onun kapısının yanına koyacam küfür edeceğim” (Katılımc1, 9) ve "Sen kör müsün?” (Katılımc1, 6) yanıtları cümle yapısı olarak eksiksiz ve doğru olmasa da verilen tepkiler gündelik hayatta yaşanabilecek gerçek bir olayla benzerlikler taşımaktadır. Çalışmada kullanılan stratejiler kapsamında bakıldığında ise, diğer bağlamlarda da olduğu gibi, kişi ve davranışların kınandığı, doğrudan suçlamaların yapıldığı ve muhatabın tehdit edildiği saptanmıştır; "Çöplerini buraya kadar çıkarıyorsun lütfen biraz daha zahmet et ve çöpe at yoksa annenle konuşacağım” (Katılımc1, 13) cümlelerinde tehdit, doğrudan suçlama ve hafif kınama stratejileriyle birlikte rica sezdirimi de söz konusudur.

\subsubsection{Bağlamda kullanılan şikâyet edim stratejilerinin değerlendirilmesi}

Bugün final sınavın var ve sınava geç kaldın. Araban yok. Bir taksiye biniyorsun ve taksiciden hızlı gitmesini istiyorsun, ama kendini trafik sıkışılı̆̆ının ortasında buluyorsun. Sınavın az sonra başlayacak ve çok sinirlisin. Sinav yerine 10 dakika geç geliyorsun. Hocan “Üzgünüm, seni sinava alamam.” diyor. Ona ne dersin?

Katılımcıların yanıtlaması istenen sorulardan beşincisi okul ortamı ile ilgilidir. Şikâyetçi bir öğrenci iken, muhatap bir akademisyendir. Katılımcıların tamamı öğrenci olduğu için verilen durum ve kendi yaşamları arasında bağlantı kurmaları amaçlanmıştır. Bir diğer değişle aktif bir öğrencilik hayatı söz konusu olmasa bile, her bireyin eğitim ortamı ile ilgili çeşitli anı ve düşüncelere sahip olduğu bir gerçektir. Bu yüzden kişinin benzer bir ortamda kendini ifade edebilmesi önem taşımaktadır ancak verilen durumda diğer bağlamlardan farklı olarak problemde şikâyetçinin de suçlu olduğu söylenebilir çünkü sınav görevlisinin sınav kurallarını uygulaması ve öğrencinin de bunu göz önünde bulundurarak tedbirli olması gerekmektedir. Yanıtlarda kullanılan stratejiler analiz edildiğinde şikâyet ediminden ziyade rica ve özür edimi stratejilerinin ön plana çıktığı saptanmıştır; “...özür dileyeceğim” (Katılımc1, 4), “hocam bahane istemiyorum geç kaldım ama bana firsat verir misin lütfen”" (Katılımc1, 6), "Pardon hocam..." (Katılımc1, 10), ve "Hocam çok özür dilerim...” (Katılımc1, 14). Bu bağlamda dikkat çeken bir husus ise taksicinin de problemin kaynağı olabileceğidir çünkü trafiğin daha az yoğun olduğu bir yer de tercih edilebilirdi; fakat katılımcılardan hiçbiri bu tür bir suçlama da bulunmamıştır; doğrudan kendisini suçlamak yerine trafik, hava koşulları gibi etmenler vasıtasıyla dolaylı suçlama stratejisini kullanmayı tercih etmişlerdir. "Hocam benim bir suçum yok ben erken çıktım ama trafik çok yoğundu” (Katılımc1, 13) cümlesi bu suçlamanın bir örneği olarak kabul edilebilir. Ayrıca katılımcılardan sadece biri konuyu bir üst makama taşıyacağını 
belirterek tehdit stratejisine başvurmuştur; “...yapacak bir sey yok bu durumda dil merkezi müdurluğa gideceğiz onu anlatacă̆ız” (Katılımc1, 2). Tehdit stratejisinin tercih edilmemesi muhatabın bulunduğu konumun etkisinin bir sonucu olarak değerlendirilebilir. Genel olarak bu bağlamda şikâyet ediminden çok rica ve özür ediminin ön plana çıktığı sonucuna varılabilir.

\subsubsection{Bağlamda kullanılan şikâyet edim stratejilerinin değerlendirilmesi}

Profesör Ayşe Hanım 'ın senin ödevine not vermesi ve pazartesi sabahına kadar onu teslim etmesi gerekiyordu. Bugün Cuma ve henüz ödevine not vermemiş. Endişelisin çünkü gelecek pazartesi ödevindeki konuyla ilgili bir sinav yapacak. Profesörü ofisinde ziyaret ediyorsun. Ona ne dersin?

Söylem tamamlama testinde bulunan sekizinci ve dokuzuncu bağlamlardaki durumlarda aynı ortamda ve benzer muhatap-şikâyetçi ikilisiyle gerçekleşen bir olay ele alınmıştır. Yalnız bu bağlamı bir önceki bağlamdan farklı kılan nokta, güçlü konumdaki muhatabın sorumluluklarını aksatmış olmasıdır. Bu durumda katılımcıdan beklenen ifade, eğitim ortamı gibi ortak bir payda söz konusuyken ders öğretmeninin işini geciktirdiği bir atmosferde iletişim becerilerini zorlanmadan kullanmasıdır. Öncelikle konuşmanın resmi bir ortamda gerçekleştirildiği düşünülürse konuşmacının muhatabına saygı çerçevesinde selam vermesi, kendini tanıtması ve şikâyetinin sebeplerini açıklaması gerekmektedir. Katılımcılardan hiçbiri kendini tanıtmamış olmakla birlikte çoğunluğu bağlama uygun bir giriş yapmamıştır. "Merhaba hocam, verdiğim ödev bana henüz teslim edilmedi...” (Katılımc1, 1), "Afedersiniz sevgili hocam ödevine not alabilir miyiz?” (Katılımc1, 6), "Merhaba hocam kolay gelsin, ben çok üzgünüm ...” (Katılımc1, 10), "Merhaba Profesor Ayşe, nasılsınız?” (Katılımcı, 18) ve "Hocam sizi rahatsız ettiğim için özür dilerim ödevimi size vermiştim..." (Katılımc1, 13) yanıtları daha yerinde girişler olarak kabul edilebilirken bazı katılımcılar doğrudan şikâyet edimine başvurmuşlardır; "Ne zaman bana vereceksiniz!” (Katılımc1, 9) ve "O not ben çok lazım” (Katılımc1, 17) örnekleri verilen bağlam doğrultusunda uygun selamlaşma cümleleri değillerdir. Bununla birlikte bir önceki bağlamla olan ortam benzerliği düşünüldüğünde bu durumda muhatap suçlu iken de herhangi bir tehdit söz konusu olmamıştır. Kullanılan stratejiler analiz edildiğinde ise, hafif kınama ve doğrudan suçlama stratejileri ön plana çıkmaktadır. Bununla birlikte muhatap ve şikâyetçi arasındaki sosyal mesafeden dolayı sezdirim stratejisine de başvurulduğu sonucuna varılmıştır; "Merhaba hocam, verdiğim ödev bana henüz teslim edilmedi ĕger bir problem varsa bana söyleyiniz lütfen" (Katılımc1, 1) yanıtında şikâyetçi durumdan kaynaklanan rahatsızlığını muhatabını suçlamadan ifade etmeye gayret etmiştir. Bununla birlikte "Lütfen bu hafta ödevlerimi yapamam çünkü sınavım var" (Katılımc1, 5) cevabında ise şikâyetçi sorunun çözülmediği takdirde nasıl bir durumla karşılaşacağını belirterek olumsuz çıkarım stratejisini kullanmıştır. Son olarak bu bağlamda diğer bağlamlardan farklı olarak durumu tam olarak kavrayamayan katılımcıların sayısının ağırlıklı olduğu sonucuna varılmıştır. "Çok pardon 
çünkü ödevime not vermidim. Çünkü pazartesi benim amacım öldü bu sebeple ben buradayım değil. Ben İzmir'e gittim ve belki iki gün sonra yapalım" (Katılımc1, 18) ifadesinde katılımc1 kendini şikâyetçiden çok muhatabın yerine koymuş ve onun adına konuşmuştur. Benzer bir yanıtın bulunduğu "Özür dilerim lütfen başka birgün sınav yapabilir miyim”" (Katılımcı, 16) ifadesi de bir bakıma soru yönergesini anlamamanın bir sonucu olarak gösterilebilir.

\subsubsection{Bağlamda kullanılan şikâyet edim stratejilerinin değerlendirilmesi}

Bir çarşamba günü saat gecenin on ikisi (24:00). İki saattir uyumaya çalışlyorsun, ama kapı komşun bir parti veriyor. Gürültü ve müzikten dolayl uyuyamıyorsun. Bu ilk kez olmuyor. Komşun geçen ay da gürültülü partiler verdi. Komşun seni ciddiye almadı̆̆ için bu kez onunla kesin bir şekilde konuşmaya karar veriyorsun. Ona ne dersin?

Söylem tamamlama testinin son bağlamında verilmiş olan durum yedinci bağlam ile benzerlik göstermektedir. Şikâyeti eden ve şikâyet edilen kişi apartman gibi ortak bir yaşam alanında ikamet eden komşulardır. Yalnız bu bağlamdaki problemin sebebi yazılı bir kuralın çiğnenmesinden ileri gelmektedir. Öncelikle soru yönergesinde belirtilmiş olan kesin konuşma vurgusu şikâyetçinin tehdit stratejisine başvuracağı öngörüsünü destekler niteliktedir. $\mathrm{Bu}$ doğrultuda katılımcıların büyük çoğunluğu yanıtlarında "polise şikâyet, polisi arama" gibi kelime öbeklerine yer vermişlerdir; "Ya sessiz olun yada polisi aracă̆ım" (Katılımc1, 1) yanıtı örnek olarak gösterilebilir. Ayrıca bağlamda verilen durum oldukça detaylandırılmış ve rahatsızlığın ciddi bir seviyeye ulaştığının altı çizilmek istenmiştir. Bu sebepten dolayı şikâyet ediminden çok rica edimine kayan ifadelerde bağlamdan uzaklaşıldığ söylenebilir; "Kendim durum anlatıp müziğin sesi kesmesine rica ediyorum" (Katılımc1, 4) yanıtı ile "Biraz gürültünüzden kesiyor musunuz. İki saattir uyumaya çalışlyorum ama sizin yüzünden olmuyor. Bu ilk defa değildir. Ĕger sesini kesmezsiniz sizi şikâyet edeceğim” (Katılımc1, 14) kıyaslandığında kibar bir ricadansa çalışmada esas alınan telafi için rica stratejisinin daha uygun olacağı söylenebilir. Bir başka deyişle, içinde bulunulan durumdan dolayı katılımcılar tarafından doğrudan suçlama, kişiden ve davranıştan dolayı kınama stratejilerinin daha çok tercih edildiği görülmüştür. "...geçen ayda gürültülü partiler yaptık lütfen sabahta erken çallşlyorum..." (Katılımc1, 10) ifadesinde davranış kınanırken, “...İki saattir uyumaya çalışıorum ama sizin yüzünden olmuyor ..." (Katılımc1, 14) yanıtında şikâyetçi doğrudan kişiyi suçlamıştır. Ayrıca dikkat çeken noktalardan birisi de "Komşum" ifadesine yer verilmesidir. "Komşum sizin

gürültünüzden uyamıyorum..." (Katılımc1, 7) ve "Komşum ben çalışlyorum..." (Katılımc1, 6) yanıtlarında da görüldüğü gibi bu tür bir bağlam için uygun bir ifade olmadığı söylenebilir. Çünkü bu tür bir ifadenin sosyal mesafenin neredeyse ortadan kalktığı, samimi ve geleneksel komşuluk ilişkilerinde yaygın olarak kullanıldığı düşünülebilir. 


\subsection{YADOT Öğrenicilerinin İletişimsel Dil Yeterliklerinin Analiz Edilmesi}

OBM' ye göre "İletişimsel hedeflerin gerçekleştirilmesi için dil kullanıcıları/öğrenenleri genel yeteneklerini dille daha yakından ilişkili olan iletişimsel yetenek ile birleştirmelidirler" (OBM, s: 103) ve bu doğrultuda "dilbilişsel, sosyodilsel, kazanılan (pragmatik) yetenekler" olmak üzere üç kategori belirlenmiştir.

\subsubsection{YADOT Öğrenicilerinin Şikâyet Ediminin Dilbilgisel Yeterlikler Açısından Değerlendirilmesi}

Çalışmada Türkçenin yabancı dil olarak öğretiminde dilbilgisel yeterlikten ziyade iletişim yetisi üzerinde durulmuştur. Aynı zamanda kelime yeteneği, dilbilgisel ve anlambilimsel yetenekler de bu kapsamda değerlendirildiği için, şikâyet edim stratejilerindeki cümle ve kelime tercihi analizine katkı sağlayacağı düşünülmüsstür. Katılımcılardan mümkün olduğu kadar doğal bir yanıt vermeleri beklenmesine rağmen, dilbilgisel açıdan eksiklikleri olan bir cümle yapısı kişinin kendini ifade etme yetisini de olumsuz yönde etkileyecektir. OBM'ye göre B2 seviyesindeki bir öğrenici "anlaşılır betimlemeler yapabilmeye, görüşünü açıklayabilmeye yetecek düzeyde dil bilgisine sahip" olması gerekir (OBM, s: 104). Katılımcıların çekim eklerini yanlış kullanımı ve cevaplardaki cümle düşüklükleri göz ardı edildiği takdirde amaçladıkları mesajları verebildiği söylenebilir; ancak bazı katılımcıların kendilerini ifade edebilecek yapıları kullanmada yetersiz olduğu da görülmüştür. Arkadaş ortamında istenmeyen bir programın değiştirilmemesi ile ilgili olan dördüncü bağlama verilen yanıtlardan biri şu şekildedir; “Ben misafir conuş değel” (Katılımc1, 11). Bu cümleyi yazan B2 düzeyindeki Filistinli katılımcı, bulunduğu seviyeye göre rahatsızlı̆̆ını anlamlı bir şekilde ifade edememiştir ve yazım yanlışı olan bir kelimeyle birlikte ne Türkçe ne de Arapçada olan bir ifade kullanmıştır. Bu bölümde en çok dikkat çeken nokta selamlaşma konusudur. Selamlaşma kalıp ifadelerin kullanıldığı bir dil işlevi olduğu için dil öğrenicilerinin kendini daha rahat ifade edebilmesine olanak tanır. Çalışmada, özellikle bozuk telefon durumunda olduğu kadar komşuluk ve eğitim ortamlarıyla ilgili olan bağlamlarda da şikâyetçinin muhatabını nasıl selamladığı dilbilgisel açıdan önem taşır. Çünkü bu durum şikâyetin nasıl edileceğini de dolaylı bir şekilde etkiler. Komşu bağlamında (7. Soru) sadece B2 seviyesindeki bir katılımcı "Merhaba Ali nasılsın? iyi misin?" (Katılımc1, 18) ve yine aynı seviyedeki kat1lımc1 "Pardon nasllsinız" (Kat1lımc1, 10) kalıp ifadelerini tercih etmiştir. Ayrıca aynı katılımcılar öğretmen öğrenci ilişkisini temel alan dokuzuncu soruda da dilbilgisel yeteneklerini göstermişlerdir. Fakat "Merhaba Profesor Ayşe”" (Katılımcı, 18) selamlaşmasındaki hitap şekli daha çok İngilizceyi anımsatmaktadır. Burada bir diğer önemli nokta ise selamlaşmanın önemli olduğu mağaza görevlisi-müşteri bağlamındaki selam verme şeklidir. Bahsedilen bağlamda sadece üç katılımcı "merhaba" ile konuşmaya başlamıştır. Özellikle C1 seviyesindeki onuncu katılımcının, tüm bağlamlarda uygun selamlama ifadelerini başarıyla kullandığı saptanmıştır. 


\subsubsection{YADOT Öğrenicilerinin Şikâyet Ediminin Sosyodilsel Yeterlikler (Sociolinguistic Competence) Açısından Değerlendirilmesi}

"Sosyodilsel yetenek, dil kullanımının sosyal boyutuyla ilgili bilgi ve becerileri konu alır" (OBM, 112). Bu yüzden dil kullanıcısının şikâyet edimine başvururken muhatabıyla kurması gereken resmi veya samimi ilişki ve ortaya çıkan söyleyiş biçem farklılıkları, tercih ettiği nezaket ifadeleri büyük önem taşımaktadır. Katılımcıların yanıtlarının analizi sonucunda, sosyodilbilgisel açıdan yeterli olduğu kadar yetersiz yanıtların olduğu söylenebilir. Öncelikle bu başlık altında incelenecek ilk yeterlik, söyleyiş biçem farklılıklarıdır. Şikâyet ediminin ve dolayısıyla kullanılan stratejilerin, problemin daha kolay bir şekilde çözülmesi adına daha etkin olmaları için, şikâyetçinin muhatabıyla hangi ortamda iletişime geçtiğinin bilincinde olması gerekmektedir. Çalışmadaki yanıtlara bakıldığında, bu konuda genellikle resmî bir ilişkinin olduğu, öğretmen öğrenci ilişkisinde şikâyetçinin muhatabına "siz" diye hitap etmesi ve konuşmaya uygun bir giriş yapması gerekirken, ulaşılan dil seviyesine rağmen bu noktanın gözden kaçırıldığı yanıtlar saptanmıştır; "O not ben çok lazım, sınav için çok önemli bana daha erken verebilir mi?" (Katılımc1, 17) yanıtı da bunlardan biridir. "Afedersiniz sevgili hocam” (Katılımc1, 6) cevabında ise hem hitap şekli hem de söyleyiş tarzı uygunluktan uzaktır. Bu doğrultuda bu yanıtlar "Hocam sizi rahatsız ettiğim için özür dilerim” (Katılımcı, 13) girişiyle kıyaslandığında, ortaya çıkan fark durumu netleştirecektir. Bir diğer önemli konu da şikâyette bulunulurken kullanılan hitap şekilleridir. Baba oğul konuşmasını içeren beşinci bağlamda verilen yanıtlardan biri "Babam ben seni çok seviyorum” (Katılımc1, 18) şeklinde iken muhatabın komşu olduğu yedinci bağlamda ise "ağabi lütfen bundan sonra evimin önüne çöp bırakmayın” (Katılımcı, 1) ifadesi kullanılmıştır. İki örnekte de hitap kelimeleri bulunduğu bağlama uygun bir şekilde dile getirilmemiştir. Çalışmadaki şikâyet edimlerinin sosyodilbilgisel yeterlik açıdan incelenmesinde ön plana çıkan bir diğer konu da nezaket kurallarıdır. Özellikle iletişimde kelime seçimi konuşmanın gidişatını şekillendirir. Örneğin, sinemada sessiz olması istenen birine "abi sessiz ol" (Katılımc1, 9) denmesi hem nezaket kuralları hem de hitap sözcügü seçimi açısından uygun değildir. Ayrıca "lütfen, pardon” gibi nezaket bildiren kelimelerin de kullanımı önemlidir ve çalışmadaki yanıtlar bu bakımdan oldukça başarılıdır. Yalnız arabanın su sıçratması bağlamında yazılan "lütfen dikkat efendim" (Katılımc1, 15) yanıtı doğallıktan uzaktır ve "efendim” ifadesinin doğru bir şekilde kullanıldığ söylenemez. Sonuç olarak yanıtlardaki şikâyet edimleri sosyodilsel yeterlik açısından çeşitlidir.

\subsubsection{YADOT Öğrenicilerinin Şikâyet Ediminin Pragmatik Yeterlikler Açısından Değerlendirilmesi}

YADOT öğrenicilerinin söylem tamamlama testine verdiği yanıtlarda dikkat çeken bir diğer önemli konu ise katılımcıların şikâyet edimini kullanırken kullandıkları cümleleri bağlama uygun bir şekilde düzenleyebilme becerisidir. Şikâyet ederken bir rahatsızlık belirtildiği için genellikle konunun açıklanması gerekmektedir. Genel olarak katılımcılar tutarlı ve mantıksal 
sıralamayı gözeten cümle sıralamalarını tercih etmişlerdir. Fakat her katılımcının her bağlamda cümleleri sebep sonuç ekseninde düzenleyebildiği söylenemez. Bu doğrultuda bağlamlar ayrı ayrı değerlendirildiğinde, bozuk telefon durumunda dil kullanıcısının mutlaka problemi detaylı anlatması gerekmektedir. Verilen cevapların büyük çoğunluğunda bu şekilde başarılı bir yol izlenmiştir.; "Bir yeni telefon aldım ama telefonda düzgün çalışmıyor ve satıcı bana yardım etmiyor ona şikâyet etmek istiyorum ve senden yardım istiyorum." (Katılımc1, 12). Sinemada gürültüden rahatsız olan kişi bağlamında ise dil kullanıcısı detaylı olarak sebebi anlatma gereği duymayabilir. Bu yüzden "sesiniz çok yüksek oluyor ve sizin yüzünden filme odaklanamıyorum. Sesinizi kısabilir misiniz? (Katılımc1, 12) cevabında olduğu gibi katılımcıların bazıları önce sebebi; “arkadaşlar ,lütfen sessiz olabilir misiniz? sinemadayız” (Katılımc1, 1) gibi bir ifade de bazıları ise önce sonucu belirtmişlerdir. Kız kardeşin havaalanında ailesini bilgilendirip bilgilendirmemesini konu alan üçüncü bağlamda ise, diğer bağlamlara nazaran daha anlaşılmaz yanıtlar verilmiştir ve tutarlı olarak kabul edilebilecek cevap sayısı oldukça azdır; "hatırlatmak için onları tekrar ediyorum" (Katılımc1, 16) , "Ben de unutacaksın Tüh" (Katılımc1, 6) , "Yani o insan alaka devam etme istemiyor ve onu söylüyeceğim görüşürüz” (Katılımc1, 15). Tutarsızlık örneği olarak gösterilen bu cevaplarda problemi çözmeye yönelik bir çaba söz konusudur. Sessiz kalma (opt out) şikâyet ediminde kullanılabilecek ilk strateji olmasına rağmen bu bağlamda sorunu ortadan kaldırmaya yönelik olmadığı söylenebilir. Ayrıca aynı bağlamda "Madem inkar ediyor, hiçbirse ona söylemeceğim, yalnız gideceğiz tabi üzülüyorum ama farketmez ona küstüyeceğim” (Katılımc1, 2) ifadesinde olduğu gibi, katılımcılar yanıtlarını doğrudan muhatabına yönlendirmek yerine cevaplarını aktarmayı tercih etmişlerdir. Cevaplar genel olarak analiz edildiğinde, bazı bağlamlar benzer ortamlarda gerçekleşmesine rağmen, cevaplardaki çeşitlilik ve anlamlılık farklı düzeylerdedir. Örneğin, üçüncü ve beşinci bağlam aile içi ilişkiler ile ilgilidir, fakat baba-oğul diyaloğundaki yanıtlar abla-kardeş konuşmasındakine göre daha tutarlı ve anlamlıdır; "Sabırlı olman lazım" (Katılımcı ,16, 5. Bağlam) cevabı, kullanılan gereklilik kipinin de (-meli/malı) etkisiyle kısa bir cümle olmasına rağmen işlevini yerine getirmiş olduğu söylenebilir. Bununla birlikte pragmatik yetenek kapsamında, cevaplardaki şikâyet edimi kullanımında küfür etme ve beddua ifadelerine ilk kez altıncı bağlam olan arabanın su sıçratmasında rastlanmıştır; "Allah ceza ver” (Katılımc1, 6) ve "Küfür ederim sessizce" (Katılımc1, 7) daha tutarlı yanıtlar olarak değerlendirilebilirken, "Allah sana affediyor bu işlem Ahlakı yok” (Katılımc1, 16) gerçeklikten uzak olarak gösterilebilir. $\mathrm{Bu}$ tür yanıtlar katılımcıların doğal yanıtlar vermeye gösterdiği özenin bir sonucu olduğu kadar onların gündelik hayatta bu tür söz öbeklerini nasıl kullandıklarına dair ipuçları olarak da değerlendirilmiştir.

\section{Tartışma}

YADOT öğrenicilerinin verilen bağlamlar doğrultusunda sözedimsel tepkilerini araştıran bu çalışmada, analiz edilen şikâyet edim stratejileri ve yapılar, benzer konulardaki çalışmalardan 
yararlanılarak değerlendirilebilir. Verilen yanıtlardan birkaçı hariç olmakla birlikte, YADOT öğrenicilerinin, şikâyet edimini uygun bir şekilde kullanmaktan ziyade, durumlarda verilen rahatsızlıklarını ifade etme konusunda başarılı olduğu saptanmıştır. Fakat katılımcıların Türkçe yeterlikleri B2, C1 ve C2 düzeyinde olmasına rağmen, farklı bağlamlarda şikâyet edimini kullanma becerilerinin dil seviyeleri ile her zaman tutarlı olmadığı görülmüşsür. Çalışmadan elde edilen sonuçlara göre en çok doğrudan suçlama stratejisi tercih edilmiştir. Moon (2001) tarafından yapılmış olan araştırmada da İngilizce öğrenicilerinin doğru stratejiyi seçmede problem yaşadıkları ve doğrudan olan stratejileri tercih ettiği sonucuna varılmıştır; elde edilen sonuç bu çalışmayla da benzerlikler taşımaktadır.

Dili öğrenen bireylerin “daha uygun edimsel dil becerisini” elde etmesini sağlamanın bir yolu da düzenli sınıf ortamından geçer (Cohen, 2005: 285). Diğer bir deyişle, bir öğrenici ne kadar çok dil eğitimine maruz kalırsa, kendini o kadar iyi ifade edebilmelidir. Bu doğrultuda dil merkezinde akademik Türkçe alan C2 seviyesindeki öğreniciler, dile hakimiyetlerinin bir sonucu olarak şikâyet edimlerini tüm bağlamlarda doğru bir şekilde ve mümkün olduğu kadar doğala yakın olarak cevaplamışlardır. Fakat B2 ve C1 seviyelerinde aynı durum söz konusu değildir. Hatta B2 düzeyindeki onuncu katılımcının C1 seviyesindeki katılımcılara göre daha anlaşılabilir ve uygun ifadeler kullandığı görülmüş̧ür. Aynı zamanda dil kullanıcıları orta ve ileri düzeyde Türkçe seviyesinde olmalarına rağmen, cümlede öğe eksiği, yapım veya çekim eklerinin hatalı kullanımı ve cümle düşüklükleri gibi temel dilbilgisi hataları yapmışlardır. $\mathrm{Bu}$ durum seviye sınavlarının edimbilimsel ve dilbilgisel beceri kullanımını ölçmesi açısından orta seviye ve ileri düzeydeki farklılıkları ön göremediğini ve YADOT öğrenicilerinin sadece edimsel açıdan değil, aynı zamanda dilsel edinç açısından da yetersiz olduğunu göstermektedir. Dörnyei ve Kormos (1998: 359) hedef dilde problem çözmede karşılaşılabilen sorunlara değinmiştir ve "mikro çerçevede mesajı kısa tutma veya değiştirme, başka dillere dönme, yeni bir kelime üretme, başka dillere dönme, doğrudan çeviri; makro planda ise alternatif dilbilgisi kuralları oluşturma" olarak maddelemiştir. Çalışmada yapılan analizler sonucu bu tür hatalara rastlanmıştır. Bazı katılımcılar üç satır uzunluğunda cevaplar verirken bazılarının ifadelerini eksik veya kısa olarak dile getirmeleri ve "sesini kısabilir misiniz-sesini kesebilir misiniz” gibi alternatif kelime kullanmaları daha çok mikro düzeyde yaşanan sorunları doğrular niteliktedir. Özellikle on birinci katılımcının "secand yok" (sıkıntı yok) ve iki farklı cümlede kullandığı “conuş” kelimeleri, katılımcının ana dili olan Arapça 'da da bulunmamaktadır, bu durumda yeni kelimeler üretilmiştir.

Etkili bir söz edimi performansından söz edilebilmesi için, öğrenilen dil ve kültürün yanında, konuşmacının muhatabının yaş, statü ve cinsiyet özelliklerini göz önünde bulundurmalıdır (Cohen: 2005). Blum-Kulka ve Olshtain (1984) edimbilim çalışmalarındaki en büyük zorluklardan birinin evrensellikle birlikte, bağlamların kültürden kültüre ve dilden dile ne ölçüde değişebildiğini belirlemek olduğunu belirtmiştir. Bu yüzden konuşmacılar arasındaki mesafe ilişkileri kültürden kültüre değişiklik gösterebilir. Amerikalıların öğretmenlerine ismiyle hitap 
etmeleri sahip oldukları kültür için oldukça sıradanken, bu durum Türkiye' de kabul edilemez bir davranıştır; fakat bu tür ilişkiler evrensel anlamda resmiyet arz ettiği ve aynı zamanda verilen bağlamların Türkçe dilinde düşünülmesi istendiği için, şikâyetçi, muhatabıyla arasında olan mesafeyi göz önünde bulundurarak iletişime geçmelidir. Bu doğrultuda çalışmada ele alınan öğrenci-öğretmen, müşteri-alıcı, izleyici-izleyici (sinemada gürültü), komşu-komşu, babaevlat, arkadaş-arkadaş, kardeş- abla/abi bağlamları konuşmanın gidişatı açısından resmiden gayri resmiye olarak sıralanabilir; yalnız şikâyet edimine başvuran her katılımcının bu statü farklılığını doğru bir şekilde göz önünde bulundurduğu söylenemez. Çalışmada en çok dikkat çeken nokta, bağlamda verilen öğretmen durumunda şikâyetçinin üçüncü çoğul şahıs yerine (siz), ikinci tekil şahıs kullanımını (sen) tercih ederek şikâyetini dile getirmesidir. Bu durum, sadece iki şikâyetçinin muhatabına "siz" diye hitap ettiği müşteri temsilcisi bağlamında da göze çarpmaktadır. Özellikle öğretmen-öğrenci bağlamındaki tutarsızlık, öğrencilerin şikâyetten çok öğretmenlerine yönelik eleştiride bulunmalarıdır ve bu sonuç Murph ve Neu (1996) tarafından yapılan çalışmanın sonuçlarıyla benzerlik göstermektedir. Yazarlara göre (Murphy ve Neu:1996) İngilizce öğrenen Koreliler de bir profesöre şikâyette bulunurken, bağlama uygun olmayan bir şekilde eleştiride bulunmuşlardır. Olshtain'ın (1983) İngilizce öğrenen İbranice konuşurları ile yaptığı çalışmada ana dili İngilizce olan Amerikalı katılımcıların önce açıklama yapıp sonra özür diledikleri fakat İbranice konuşurlarının açıklama yapmadan sadece özür diledikleri sonucuna varmıştır. Yazarın (Olshtain:1983) bu tür dile özgü tercihlerin yabancı dil öğrenicisinin hedef dilde bağlama uygun olmayan kullanımlara başvurmasına sebep olduğu iddiası YADOT öğrenicilerinin cevaplarıyla ilişkilendirilebilir. Fakat bazı bağlamlarda da doğala yakın cevaplar verilmiştir; kamusal alanı ilgilendiren bir bağlam olan sinemada gürültü durumunda çoğunluk resmi bir ifadeyle şikâyetini belirtirken, aile ortamlarını ilgilendiren bağlamlarda, samimi ifadeler tercih edilmiştir.

İlişkilerdeki mesafenin şikâyet ediminde tercih edilen stratejilerin doğrudan veya dolaylı olma özelliklerini ve bu durumun ortaya konan inceliği ne ölçüde etkilediği de önemli bir konudur. Goffman (1967) iletişim esnasında konuşmacıların sahip olduğu yüzden bahseder. Bir başka deyişle "bireyler, günlük yaşam içinde etkileşim kurdukları taraflara, duruma ve mekana göre farklı yüz sunumları içine girer" (Kansu-Yetkiner, 2008: 33). Brown ve Levinson (1987: 61) ise yüz kavramını geliştirerek, muhatap tarafından kabul görmeyi temel alan "olumlu" ve muhatabın müdahalesini engellemeye yönelik olan "olumsuz” yüz kavramları üzerinde durmuştur. Şikâyet edimi bu çerçevede olumsuz yüz ile ilişkilendirilebilir. Fakat yapılan analizlere göre, bu durum bağlamdan bağlama değişiklik göstermiştir. Cevaplarda analiz edilen rica ve özür ifadeleri olumlu yüz kavramını da ön plana çıkarmıştır. Öncelikle "Türk kültüründe yüz, saygı ile ilişkilendirilir ve kişinin sosyal hayattaki ününe, prestijine, özgüvenine, kendine verdiği değere ve ahlaki bütünlüğe işaret eder” (Kansu-Yetkiner, 2006: 27). Bu yüzden Türkçe konuşurlarının özellikle öğretmen-öğrenci ilişkisini, baba-evlat konuşmasını, arkadaş ortamını ve komşuluk ilişkisi temel alan bağlamlarda, bulunulan ortamda kabul görmek için olumlu yüze 
başvurmaları beklenmektedir. Dolayısıyla, müşteri hizmetlerini, aile ortamını, çamur sıçratmayı konu edinen şikâyetlerde kabul görme kaygısından ziyade oluşan rahatsızlığı gidermeye yönelik olumsuz yüz stratejilerinden faydalanılmıştır ve "lütfen, pardon, özür dilerim” gibi rica ve özür ifadelerinden kaçınılmıştır. Fakat analiz edilen şikâyet sözcelemlerinden yola çıkılarak okul ve komşuluk ortamını ele alan bağlamların bu varsayımla örtüşmediği görülmüştür. Bu noktada öğretmen-öğrenci ilişkisini ele alan sekizinci ve dokuzuncu bağlamlarda, şikâyetçinin (öğrencinin) hatalı olduğu durumda şikâyetçi oldukça olumlu yönde bir algı oluşturma çabası içindeyken, muhatabın (öğretmenin) şikâyete sebebiyet verdiği durumda ise, şikâyetçi edilgen yapılardan kaçarak, olumsuz yüz stratejilerini tercih etmiştir, ki bu sonuç Türk kültüründeki yüz kavramlarıyla ve Brown ve Levinson'ın (1987) olumsuz yüz stratejileriyle uyuşmamaktadır. Bu noktada Hymes'ın (1972) yabancı dil öğrenen bireylerin içinde bulunduğu topluluğun kültürel normlarını anlamazsa başarılı bir iletişim kurmada problemler yaşayabilir iddiası da sonuçları destekler niteliktedir. İncelik kuramıyla birlikte "inceliğin derecesi arttıkça, edimsözdeki kibarlık da arttırılmalıdır çünkü istemliliğin (optionality) de derecesi artar, bir söz edimi ne kadar dolaylı olursa, etkisinin kalıcılığı ve gücü de o kadar azalır" (Leech, 1983: 108) iddiası da konuyla ilişkilendirilebilir. Bu iddiaya göre, her bağlamda sıklıkla kullanılan "pardon, lütfen” gibi rica ve özür ifadelerine, daha çok dolaylı şikâyet edim stratejilerinde rastlanması gerekmektedir. Fakat yapılan analizler doğrudan şikâyet edim stratejilerinde de kibarlık anlamı katan "-e/a + bilmek" ekinin kullanıldığını göstermiştir. Aynı zamanda dolaylı ifadelerle yapılan şikâyetlerde ise emir cümleleriyle birlikte kaba ifadelere de sıklıkla rastlanılmıştır. Leech'e göre (1983) en dolaylı ve kibar ifadelerin öğretmen-öğrenci ilişkisini ele alan bağlamlarda kullanılması gerekirken, verilen yanıtlarda "lütfen, pardon, kusura bakmayın, özür dilerim" kelimelerine rastlanmasına rağmen doğrudan şikâyet edim stratejileri tercih edilmiştir. Başka bir deyişle resmiyetin olmadığı arkadaş ortamında da şikâyet edimi kullanımında samimi ve kibar bir dil tercih edilmiştir; fakat dolaylılıktan ziyade emir ve doğrudan rica ifadelerinin kullanımı ön plana çıkmaktadır. Sonuç olarak nezaket belirten ifadelere sıklıkla rastlanmıştır ama bağlama ve cümle yapısına uygun doğru bir şekilde kullanılmadıkları için inceliğin dolaylılığı ya da doğrudanlığı doğrudan etkilediği söylenemez. Çalışmanın sonuçları Blum-Kulka’nın (1987) dolaylılığın incelikle paralel olarak azalıp artmadığı ve en doğrudan olanın en ince olarak değerlendirilemeyeceği iddiasını desteklemektedir. Bir başka deyişle dolaylı ifadelere yer verilmemesi ve edilgen ifade kullanımından kaçınılması dil kullanıcılarının dile yeterince hâkim olmamalarından kaynaklanan bir sonuç olarak görülmüştür. "Fiilde Çatı" ve imayı kullanma konuları B2 düzeyinde edinilmiş olması gerekirken, sadece $\mathrm{C} 1$ seviyesindeki bir öğrenici ve C2 düzeyindeki iki öğrenici şikâyet edimine başvururken edilgen yapıyı kullanmıştır (OBM).

\section{Sonuç}

Bu çalışmada Türkçenin yabancı dil olarak öğretimi sürecinde YADOT öğrenicilerinin, gündelik yaşam esas alınarak hazırlanmış olan çeşitli bağlamlarda şikâyet söz edimlerini ne 
ölçüde kullanabildiği ve bu doğrultuda hangi şikâyet edim stratejilerinin tercih edildiği hususları üzerinde durulmuştur. Bu bağlamda YADOT öğrenicilerinin söylem tamamlama testine verdikleri yanıtların analizi sonucunda elde edilen bulgular, çalışmada esas alınan temel ve alt araştırma problemlerinin çözümüne katkı sağlar niteliktedirler ve şu şekilde sıralanabilirler;

1. YADOT öğrenicilerinin, çalışmada esas alınan Trosborg (1994) tarafından oluşturulan ve Bikmen \& Martı (2013) tarafından geliştirilen on bir temel stratejiden en çok doğrudan suçlama stratejisi tercih edilmiştir.

2. YADOT öğrenicilerinin Türkçe yeterlilikleri B2, C1 ve C2 düzeyinde olmasına rağmen, farklı bağlamlarda şikâyet edimini kullanma becerilerinin dil seviyeleri ile her zaman tutarlı olmadığ1 görülmüştür.

3. YADOT öğrenicilerinin kullanıldıkları bağlamlar bakımından iç içe geçebilen rica, özür ve şikâyet edimlerini ayırt etmede zorlandıkları ve bu edim türlerini birbirlerinin yerine kullanma eğiliminde oldukları saptanmıştır. Bu yüzden çalışmanın odağı şikâyet edim stratejileri olmasına rağmen, her bağlamda rica ve özür edimi ifadelerinin de tercih edildiği görülmüştür.

4. Bilinen yabancı dil sayısındaki artış ve kullanılan şikâyet edim stratejilerinin çeşitliliği arasında bir ilişki saptanmamıştır.

5. YADOT öğrenicilerinin, dil kullanım alanları açısından hangi alanda şikâyet edim stratejilerini daha etkin bir şekilde kullanıp kullanmadığına dair önemli bir bulgu elde edilmemiştir.

6. YADOT öğrenicilerinin şikâyet söz edimlerini kullanırken dilbilgisel yeterlik açısından kendini ifade etme becerisine sahipken sosyodilsel ve pragmatik yeterlik açısından beklenen seviyede olmadığı görülmüştür.

7. Çalışmada bir değişken olarak ele alınan cinsiyet faktörünün YADOT öğrenicilerinin şikâyet edimi kullanımında bir etkisi olmadığı saptanmıştır.

8. Çalışmadaki katılımcıların Türkiye'de bulunma süreleri 3 ay ve 2 sene arasında değişiklik göstermesine rağmen kalma süreleri Türkçe yeterlik seviyeleri ile tutarlı olmamakla birlikte kullanılan şikâyet edim stratejilerinin çeşitliliğinin kullanımında da önemli bir değişken olarak görülmemiştir.

9. YADOT öğrenicilerinin şikâyet edimini gerçekleştirirken muhatapları ile içinde bulundukları sosyal mesafeye gerekli dikkati göstermemekle birlikte, konuşmanın resmi ya da resmiyetten uzak bir çerçevede gerçekleştiğini anlamada gereken başarıyı gösterememişlerdir.

10. Yaygın görüşün aksine dolaylı edim stratejilerinin kullanıldığı bağlamlarda, doğrudan edim stratejilerinin baskın olduğu durumlara nazaran daha çok incelik belirten ifadelere başvurulmamıştır; incelik belirten ifadeler kalıp kelime kategorisinde ele alınıp her bağlamda kullanılmıştır. 
11. YADOT öğrenicilerinin Türkçedeki kalıp ifadeleri kullanmada sorun yaşamadıkları; ancak kalıp ifadeleri uygun bağlamlarda kullanmada başarılı olamadıkları görülmüştür ve bununla birlikte konuşmaya girişte kullanılan selamlama kelimelerini de bağlama uygun bir şekilde kullanamadıkları görülmüştür.

Hakem Değerlendirmesi: Dış bağımsız.

Çıkar Çatışması: Yazarlar çıkar çatışması bildirmemiştir.

Finansal Destek: Yazarlar bu çalışma için finansal destek almadığını beyan etmiştir.

Peer-review: Externally peer-reviewed.

Conflict of Interest: The authors have no conflict of interest to declare.

Grant Support: The authors declared that this study has received no financial support.

\section{Kaynakça/References}

Altun Alkan, H. (2019). Rica Ediminin Türkçeyi Yabancı Dil Olarak Öğrenenler Tarafindan Kullanımları (Yayımlanmamış yüksek lisans tezi). Pamukkale Üniversitesi, Denizli.

Aşkın Balcı, H. (2017). Relation of pragmatics and grammar, International Journal of Languages' Education and Teaching, 5 (4), 556-566.

Austin, J.L., (2009). How To Do Things With Words. (Çev. R. L. Aysever). İstanbul: Metis Yayınları. (Orijinal yayın tarihi, 1975).

Bayat, N. (2017). Türkçenin yabancı dil olarak öğretiminde şikâyet ve özür edimine ilişkin görünümler. $P A U$ Eğitim Fakültesi Dergisi, (41), 1-16.

Beals, R. L. ve Hoijer, H. (1991). Antropolojinin konusu ve alanı. Ankara Üniversitesi Dil ve Tarih - Coğrafya Dergisi, 35 (2) (Çev. G. Erginer) (Orijinal yayın tarihi 1972).

Bikmen, A. ve Martı, L. (2013). İngilizce öğrenen Türklerin şikâyet söz eylemi üzerine bir çalışma. Education and Science, 38 (170), 253-265.

Birner, B.J. (2013) Introduction to Pragmatics. UK: Wiley-Blackwell.

Blum-Kulka, S. ve Olshtain, E. (1984). Requests and apologies: a cross-cultural study of speech act realization patterns (CCSARP). Applies Linguistics, 5 (3), 196-213.

Blum-Kulka, S. (1987). Indirectness and politeness in requests: same or different?. Journal of Pragmatics, $11,131-146$.

Boxer, D. (1991). A Descriptive Analysis Of Indirect Complaint Sequences Among Speakers Of American English (Yayımlanmamış doktora tezi). Pennsylvania Üniversitesi, Philadelphia.levinsonBrown, P. ve Levinson, S. C. (1978). Universals in language usage: Politeness phenomena. E. Goody (Ed.), Questions and Politeness: Strategies in Social Interaction (ss. 56-324). Cambridge: Cambridge University Press.

Brown, P. ve Levinson, S. C. (1987). Politeness: Some Universals in Language Usage. Cambridge: Cambridge University Press.

Campbell, R ve Wales, R. (1970). The study of language acquisition. J. Lyons (Ed.), New Horizons in Linguistics (Chapter 13). New York: Penguin Books.

Chomsky, N. (1965). Aspects Of The Theory Of Syntax. Massachusett: The M.I.T. Press.

Cohen, A. (2005). Strategies for learning and performing L2 speech acts. Intercultural Pragmatics, 2 (3), 275-301. 
Demirezen, M. (1991). Pragmatics and language teaching. Hacettepe Üniversitesi Eğitim Fakültesi Dergisi, 6, 281-287.

Dörnyei, Z., Kormos, J. (1998) Problem-solving mechanisms in L2 communication, Studies in Second Language Acquisition, 20, 349-385.

Ellis, R. (1994). The Study of Second Language Acquisition. Oxford: Oxford University Press.

Fidan, D. (2017). Söz edimi kuramına genel bir bakış ve eğitim ortamlarında kullanımı: Diksiyon dersleri için bir etkinlik denemesi. Turkish Studies-International Periodical Languages, Literature and History of Turkish or Turkic ,12 (25), 373-400.

Goffman, E. (1967). Interaction Ritual: Essays On Face To Face Behavior. New York: Garden City.

Grice, P. H. (1989). Studies in the Way of Words. Cambridge: Harvard University Press.

Hymes, D. (1972). On communicative competence. J. B. Pride ve J. Holmes (Ed.), Sociolinguistics (ss. 269293). Harmondsworth: Penguin Books.

Kansu Yetkiner, N. (2006). Blood, Shame And Fear: Self-Presentation Strategies Of Turkish Women's Talk About Their Health And Sexuality (Yayımlanmamış doktora tezi). Groningen Üniversitesi, Hollanda.

Kansu Yetkiner, N. (2008). İncelik kuramı ve yüz olgusu bağlamında çeviri çalışmalarında işlevsel-edimbilimsel eleştiri yöntemi uygulaması. Dilbilim Araştırmaları, 19 (1), 32-48.

Leech, G. N. (1983). Principles of Pragmatics, New York: Longman Linguistics Library.

Mey, J. L. (1993). Pragmatics: An Introduction. Oxford: Blackwell.

Moon, K. (2001). Speech act study: differences between native and nonnative speakers' complaint strategies. https://dra.american.edu/islandora/object/tesolworkingpapers\%3A18 sayfasından 16 Ağustos, 2019 tarihinde erişilmiştir.

Murphy, B. ve Neu, J. (1996). My grade's too low: the speech act set of complaining. S. M. Gass ve J. Neu (Ed.), Speech Acts Across Cultures: Challenges to Communication in Second Language (ss. 191-216). Berlin: Mouton de Gruyter.

Olshtain, E. (1983). Sociocultural competence and language transfer: The case of apology. S. M. Gass ve L. Selinker (Ed.), Language Transfer In Language Learning. Issues In Second Language Research (ss. 232249). Amsterdam: John Benjamins Yayıncılık.

Polat, Y. (2010). Yabancı dil öğretiminde söz edimleri (Yayınlanmış doktora tezi). Ankara Üniversitesi Sosyal Bilimler Enstitüsü, Ankara.

Polat, Y. (2011). Yabancı dil öğretimi kitaplarında söz edimi öğretimi. Dil Dergisi, 153 (Temmuz-AğustosEylül), 24-42.

Searle, J. R. (2006). Zihin, Dil, Toplum. (Çev. A. Tural). İstanbul: Litera Yayıncılık. (Orijinal yayın tarihi 1998).

Searle, J. R. (2011). Söylemek ve Anlatmaya Çalışmak. (Çev. L. Aysever). Ankara: BilgeSuYayınevi. (Orijinal yayın tarihi 1979).

Searle, J. R. (2016). Bilinç ve Dil. ( Çev. M. Macit). İstanbul: Litera Yayıncılık. (Orijinal yayın tarihi 2005).

Trosborg, A. (1995). Interlanguage Pragmatics. Requests, Complaints and Apologies. New York : Mouton de Gruyter.

Trosborg, A. ve Shaw, P. (1998). "Sorry does not pay my bills" the handling of complaints in everyday interaction/cross-cultural business interaction. Hermes, Journal of Linguistics, 21, 67-94.

Yian, W. (2008). A study of the speech act of complaining: Cross-cultural perspectives and interlanguage perspectives. Intercultural Forum, 1 (2). 